Egyptian Journal of Rabbit Science, 27 (2): 155- 169 (2017)

\title{
ANALYSIS OF METHODS TO FOUND NEW RABBIT LINES
}

\author{
M. Baselga' ${ }^{1}$ M. Ragab ${ }^{2}$, C. Mínguez ${ }^{3}$ and A. G. EL Nagar 4 . \\ ${ }^{I}$ Dept. Ciencia Animal, Universidad Politécnica de Valencia, Camino de Vera s/n, 46022 \\ Valencia, España mbaselga@dca.upv.es. ${ }^{2}$ Poultry Production Department, Faculty of \\ Agriculture, Kafr El-Sheikh, Kafr El-Sheikh University, Egypt. ${ }^{3}$ Carrera de Medicina \\ Veterinaria y Zootecnia, Universidad Politécnica Salesiana, Calle Vieja 12-30 y Elia Liut, \\ Cuenca, Ecuador. ${ }^{4}$ Department of Animal Production, Faculty of Agriculture at \\ Moshtohor, Benha University, Egypt.
}

\section{ABSTRACT}

The most important issues of the meat rabbit breeding are discussed, particularly the ones related to the foundation and selection of specialized lines, paternal and maternal, to be used in a scheme of three way crossing. Special attention is given to the analysis of different approaches to found new lines, but are also commented the methods and criteria of selection and the responses obtained in different programmes. A comparison is made among four maternal lines, founded on different criteria and sharing the same environment for long periods of time. Important differences were detected for litter size, fertility, growth and longevitybetween the lines attheir origin, which can be explained based on the selectioncriteria used at the time of their foundation. Therefore, all the issues related with the foundation of a new line should be carefully considered. The foundation of a line exclusively based on the concept of breed without considering production criteria seems less suitable than other criteria more closely related to production.

Key words: Rabbit, genetic improvement, lines, genomic selection.

\section{INTRODUCTION}

Until now, meat rabbit breeding is based on methods of quantitative genetics that do not include genomic information. This paper will comment briefly on the current situation of rabbit breeding and will discuss the interest of genomic selection for the rabbit in the next future.

The main focus of the paper will be related to one central issue of rabbit breeding: the foundation of new lines of rabbits that will be used later to produce rabbit meat following a crossbreeding scheme. Other important issues of a rabbit breeding program like the objectives of 
selection, methods of genetic evaluation, response to selection or diffusion of the genetic responses have been frequently reviewed (Rouvier, 1980; Matheron and Poujardieu, 1984; Rochambeau, 1988; Blasco, 1996; Baselga, 2004, Garreau et al, 2004; Khalil and Al-Saef, 2008; Khalil and Bolet, 2010; Mocé and Santacreu, 2010 ) but less attention has been given to discuss the alternatives to found new lines.

\section{Types of lines}

From a production point of view, the two most important types of animals in a rabbit farm are the does and the young rabbits. It is necessary that the does are efficient producing weaned rabbits, and that these rabbits growth fast, have a good conversion index and acceptable carcass quality. Consequently, a program of selection must be focused on improving the efficiency of these two types of animals. It could be achieved using crossbred does and young, mating specialized lines following a three way crossbreeding scheme, that requires a double cross. The first cross is the mating of does pertaining to a maternal line to bucks of another maternal line to get the crossbred does. These does, in the second cross, are mated to bucks of a paternal line to obtain the young. Thus, in this scheme, the development and genetic improvement of maternal and paternal lines is a central activity of a program of rabbit breeding. The oldest program, currently active, is the French Program conducted by the INRA that in 1969 began the development of specialized lines (Rouvier, 1981). It was followed by the Spanish program carried out jointly by the Polytechnic University of Valencia and IRTA that started in 1976 (Baselga, 2004). Other countries, as Egypt, Saudi Arabia (Youssef et al., 2008), Hungary and Italy, have now live programs based on the use of crossbreeding.

\section{Founding new lines}

The first issue to be that appears, related to the lines of a program of genetic selection is their availability, and if there are not lines available, which could be the procedures and criteria that we can follow to constitute or found the adequate lines? Sometimes, different breeds have been used in place of the lines but, in general, the breeds are entities too large and variable to be used in rabbits to obtain repeatable results, especially for the more cosmopolitan breeds that can have populations of very different performance. Thus, it is preferable to rely on smaller groups of animals, as the lines, to which a definite program of selection can be applied, depending on the specialization of the line, being their results in the crosses more predictable. Next we develop different approaches to found new lines. 


\section{The approach based on a breed}

The most common practice in the past was to rely on the existing breeds and to get samples, in several farms, of one or several breeds (Lukefahr et al., 1996) in order to create a new population of small size that after two or three generations of inter-se mating gives rise to the new line (Khalil and Baselga, 2002). The final size of the line can range between 100-200 does and 20-40 bucks. The breeds New Zealand White and California have been commonly used for this purpose. The base to found the line A of the Polytechnic University of Valencia was the New Zealand White breed (Ragab and Baselga, 2011), sampling rabbits from farms near Valencia, but there are recent examples concerning other breeds like the "Argenté de Champagne" that has been used to found the Italian paternal line named "Italian Silver". This procedure is not difficult to carry out but care must be taken because some problems can arise. One problem comes from the aforementioned enormous diversity that can exist within a breed. This means that you may sample the founder stock for the new line from populations of the breed that are genetically poor for the traits of interest and consequently the starting point for the new line will be low and possibly non-competitive. Another setback could be the health problems that could appear when all the founders are put together in the same herd but come from a relatively large number of different farms. This latter problem can be overcome by using hysterectomy or other techniques such as freezing and transfer of embryos to obtain animals from the farms (García-Ximénez et al., 1996).

\section{Sampling from outstanding populations}

Here, the first point is to realistically define the desired specialization of the line. Then, it must be attempted to find two or three populations, no matter their genetic origin (pure breed, synthetics or crossbred), that are clearly outstanding on the important traits regarding the desired specialization of the line (Baselga, 2002). The next step is to obtain animals from these populations and mate them without selection for two or three generations. This approach was followed to found the line V (UPV, Spain; Ragab and Baselga, 2011), founded in 1980 as a synthetic line, crossing animals that were progeny of four specialized maternal lines.

\section{Applying high intensities of selection}

This method needs, also, to have well defined the specialization of the new line. It relies on applying very high intensities of selection for the traits of interest in very large populations (for example, commercial populations). We illustrate this procedure detailing the foundation of line $\mathrm{H}$ 
(UPV, Spain). It is based on the detection of does named hyperprolific, screening a large population of commercial rabbits, spread over different Spanish farms. A doe was classified as hyperprolific if it had a parity with 17 or more young born alive or if the accumulated number of live born along all its parities allowed its classification in the group of the best $1 \%$. An initial step in the process was to obtain male progeny from a batch of hyperprolific does (20) mated to normal bucks ( 9 bucks, pertaining to line $\mathrm{V})$. In the second step, the males obtained in the first step were backcrossed to a new and larger batch of hyperprolific females, in order to accumulate the genes for prolificacy in the progeny. The progeny obtained was the starting generation of line $\mathrm{H}$ (generation 0 ). In this alternative, the health problems could be important and to avoid them hysterectomies were performed in the first step and embryo vitrification in the second step. After thawing and transferring these embryos, a set of 474 rabbits of generation 0 were allowable for maintaining the line and for studies of comparison of the line $\mathrm{H}$ with the line $\mathrm{V}$ and crossbred does $\mathrm{AxV}$, being the comparison successful for line H (Cifre et al., 1998 a \& b). The same alternative has been applied to create the line LP (UPV, Spain) for which the criteria of screening in the commercial farms were hyperlongevity and prolificacy over defined thresholds (more than 28 parities and a prolificacy mean of more than 7.5 rabbits born alive). In this case, three steps of backcrosses have been performed and the details of its foundation and the results of its comparison to line $\mathrm{V}$ have been given by Sánchez et al. (2008). The results confirm the utility of using very high intensities of selection for the creation of new lines and in this case, additionally, the line LP has resulted peculiarly robust to environmental challenges related to management, temperature, feeding or immune response (Theilgaard et al., 2009; Savietto et al., 2012; Ferrian et al., 2013).

\section{Comparison at foundation of lines founded with different criteria}

The nucleus of rabbit breeding of the Polytechnic University of Valencia has maintained since 1980 until now several of its lines (A, V, H and LP) sharing the same housing, management and feeding. The periods shared between two lines always begun at the time of foundation of the youngest one and remained until nowadays with the only exception of line $\mathrm{H}$ that in June of 2004 was moved from the nucleus to another farm. This peculiarity has allowed to compare the values of the different lines at their times of foundation for traits regularly recorded as litter size traits, interval between parities, growth and longevity traits. To do it all the records of the lines for a given trait were analyzed using mixed animal models specific 
for each type of traits (Ragab and Baselga, 2011; Mínguez, 2014; El Nagar, 2015). All models included among other effects, the combination line-year-season as fixed factor, and the additive effect as a random factor, and took into account the complete pedigree. The line-year-season combination forced the comparison between two lines to the year-seasons shared for both lines. The inclusion of the additive effect in the models allowed to explain the response to selection through the change of the additive values of the animals along the generations and to interpret the comparison between the lines as differences between them at foundation, relating the results of the comparisons to the criteria of foundation. The procedures of foundation of the lines A, V, H and LP have been indicated in the previous sections. The year of foundation was, 1980 for line A, 1982 for line V, 1996 for line H and 2003 for line LP. All the lines have been selected for litter size at weaning after their foundation. All comparisons between couples of lines were made with the only exception of the comparison between the lines H and LP that only shared a short period at the UPV nucleus between 2003 and 2004.

The number of records considered in the analysis and the crude means for the different traits are shown in Table 1. The records were got since the foundation of the lines until 2009 for litter size traits and kindling interval, until 2012 for growth traits and until 2015 for longevity. Consequently the crude means given in Table 1 are averages of records across lines and generations within lines, that could be very different depending of the line and generation. However, the interest of these means is to give a general indication of the productive level of the lines considered. If only data from the most recent generations were retained, higher weaning prolificacy would be observed. Thus, the averages of number weaned in generations $43^{\text {th }}, 38^{\text {th }}, 22^{\text {th }}$ and $8^{\text {h }}$ of lines $\mathrm{A}, \mathrm{V}, \mathrm{H}$ and LP were 8.4, 8.2, 8.8 and 8.3, respectively. The increase with respect to the overall average is clear and it is partially a consequence of the success of the selection process.

The contrasts regarding litter size traits and kindling interval are shown in Table 2. At their respective times of foundation, line A showed the lowest litter size with mean differences (1.39 rabbits/litter for total born, 1.20 for number born alive, 0.84 for number weaned and 1.06 for number marketed) among the combined means of the other lines being important. Lines $\mathrm{V}$ and $\mathrm{H}$ did not show significant differences for litter size traits, but for kindling interval the contrast was3.30 \pm 0.72 days, which was significant and favorable to line H. LP exceeded V by approximately one 
Table 1. Number of records $(\mathrm{N})$ and crude means (Mean) for the studied traits

\begin{tabular}{|c|c|c|c|c|c|}
\hline Trait & $\mathrm{N}$ & Mean & Trait & $\mathrm{N}$ & Mean \\
\hline Total born (kit/litter) & 47132 & 9.80 & Weaning weight (g), $28 \mathrm{~d}$ & 323208 & 570 \\
\hline $\begin{array}{l}\text { Number born alive } \\
\text { (kit/litter) }\end{array}$ & 47132 & 9.07 & Slaughter weight (g) $63 \mathrm{~d}$ & 300553 & 1860 \\
\hline $\begin{array}{l}\text { Number } \\
\text { (kit/litter) }\end{array}$ & 47097 & 7.79 & Average daily gain $(g / d) 28-63 d$ & 300553 & 36.7 \\
\hline $\begin{array}{l}\text { Number marketed } \\
\text { (kit/litter) }\end{array}$ & 43265 & 6.95 & LPL $^{1}(d)$, censored & 5150 & 268 \\
\hline Kindling interval (d) & 34356 & 49.80 & LPL (d), uncensored & 7736 & 166 \\
\hline
\end{tabular}

Table 2. Contrasts at foundation between lines (A,V,H and LP) for litter size traits and kindling interval

\begin{tabular}{|c|c|c|c|c|c|}
\hline Trait & $A-V$ & A-H & A-LP & V-H & V-LP \\
\hline Total born (kit/litter) & -1.35 & -1.76 & -1.07 & -0.09 & -0.96 \\
\hline & $\pm 0.04 *$ & $\pm 0.16^{*}$ & $\pm 0.08^{*}$ & \pm 0.19 & $\pm 0.08^{*}$ \\
\hline Number & -1.24 & -1.25 & -1.11 & -0.02 & -1.32 \\
\hline (kit/litter) & $\pm 0.04 *$ & $\pm 0.17 *$ & $\pm 0.09^{*}$ & \pm 0.19 & $\pm 0.08 *$ \\
\hline Number weaned (kit/litter) & -0.90 & -0.75 & -0.87 & -0.32 & -0.96 \\
\hline $\begin{array}{l}\text { Number } \\
\text { (kit/litter) }\end{array}$ & $\begin{array}{l} \pm 0.04 * \\
-1.51 \\
\pm 0.04 *\end{array}$ & $\begin{array}{l} \pm 0.17 * \\
-0.93 \\
\pm 0.16^{*}\end{array}$ & $\begin{array}{l} \pm 0.11^{*} \\
-0.73 \\
\pm 0.13 *\end{array}$ & $\begin{array}{l} \pm 0.19 \\
-0.29 \\
\pm 0.17\end{array}$ & $\begin{array}{l} \pm 0.10^{*} \\
-0.97 \\
\pm 0.11\end{array}$ \\
\hline Kindling interval (d) & $\begin{array}{c}0.36 \\
\pm 0.21\end{array}$ & $\begin{array}{l}1.44 \\
\pm 0.44 *\end{array}$ & $\begin{array}{l}2.92 \\
\pm 0.38 *\end{array}$ & $\begin{array}{l}3.30 \\
\pm 0.72 *\end{array}$ & $\begin{array}{l}0.83 \\
\pm 0.19 *\end{array}$ \\
\hline
\end{tabular}

*: Contrast significant; type 1 error for significance, $\alpha=0.05$.

rabbit for all litter size traits. The differences between the lines for kindling interval werenot important. Some interactions between lines and farmyear-seasons were important.The results showed in Table 2 have some apparent inconsistencies. For example, thecontrast between lines A and V for total born was -1.35 rabbits and -1.07 between A and LP. but between $\mathrm{V}$ and LPwas not 0.28 (1.35-1.07), it was -0.96 . The explanation ofthese non-real inconsistencies is attributable to the differentsets of farm-yearseasons and their interactions with the linesinvolved in the different contrasts. Concerning interactions, certain situations occurredacross the years at the UPV farm that could explain some of the farm-year-season $x$ line interactions. Firstly, the spread ofthe enterocolitis disease affected a large period in thecomparison between the lines $\mathrm{A}$ and $\mathrm{H}$. The consequence ofthis disease was an increase in the post-weaning mortality,reducing the number of rabbits marketed. However, thesensitivity of the lines to enterocolitis was different, line Abeing the line most affected. Consequently, this eventpenalized line $\mathrm{A}$ in all line comparisons for 
number marketed.Secondly, there was a change in mating management thataffected the lines V and LP from December 2003 to November2005, which increased the period of restricted feeding by 2 weeks between weaning and the next parity. This restrictionaffected line $\mathrm{V}$ more than line LP (Theilgaard et al., 2007; Sánchez et al., 2008) because the line LP showed a bettermanagement in the body reserves, being consequently lessaffected by the temporal restriction of feeding (Theilgaard et al., 2007). At foundation, lines V, H and LP showed superiority overline A (Table 2), which could be simply explained by thecriteria used for their foundations. Lines V, H and LP werecreated by mating does and bucks of different origins frompopulations that had been subjected previously to selectionfor prolificacy. Line A was created by mating does and bucksof the New Zealand White breed (obtained from severalcommercial populations) that primarily maintained thestandards of the breed more than selective improvementfor productivity. It can be also noted the advantages of line $\mathrm{H}$ in prolificacy and fertility (lower kindling intervals) that could be attributed to the procedure of its foundation, based on hyper prolificacy.

Table 3.Contrasts at foundation between lines (A, V, H and LP) for growth traits.

\begin{tabular}{cccccc}
\hline Trait & A-V & A-H & A-LP & V-H & V-LP \\
\hline Weaning weight (g), 28 d & 28 & -24 & -66 & -59 & -120 \\
& $\pm 12^{*}$ & \pm 0.14 & $\pm 16^{*}$ & $\pm 14^{*}$ & $\pm 16^{*}$ \\
Slaughter weight (g) 63 d & 70 & -142 & -217 & -214 & -372 \\
& \pm 38 & $\pm 33^{*}$ & $\pm 34^{*}$ & $\pm 0.49^{*}$ & $\pm 57^{*}$ \\
Aver. daily gain (g/d) 28-63d & 0.51 & -3.99 & -5.18 & -4.19 & -6.99 \\
& \pm 0.78 & $\pm 0.77^{*}$ & $\pm 0.80^{*}$ & $\pm 1.12^{*}$ & $\pm 1.33^{*}$ \\
\hline
\end{tabular}

*:Contrast significante; type 1 error for significante, $\alpha=0.05$.

The contrasts regarding growth traits are shown in Table 3. The comparisons showed that line A was significantly superior to line V for weaning weight. Feki et al. (1996) obtained higher values for weaning weight in favour of the A line compared to the $\mathrm{V}$ line, but in this case the differences were not at foundation, and no correction for litter size was conducted in the statistical model. The comparisons between the $\mathrm{H}$ and LP lines with lines A and V (A-H, V-H, A-LP and V-LP) showed that the lines $\mathrm{H}$ and LP were the heaviest for weaning weight and slaughter weight and had the highest average daily gain. Cifre et al. (1998b) compared the $\mathrm{H}$ line at foundation with the contemporary generation of the $\mathrm{V}$ line and found that the $\mathrm{H}$ line was always significantly heavier than the $\mathrm{V}$ line for weaning weight, and also had a higher slaughter weight, although the average daily gain was not significantly different. It must be noted that in this case the interaction line-year-season was not fitted into the model. We 
remember that this factor and the different year-seasons shared by the lines are the responsible of the apparent inconsistencies of Table 3. Considering the procedures for founding $\mathrm{A}, \mathrm{V}, \mathrm{H}$ and LP lines these results make sense, as the first two lines were created from NZW (line A) and from maternal lines (line V), while the last two were created from apparently crossbred does coming from commercial populations. These does should be true crossbreds of two maternal lines, but sometimes farmers do selfreplacement with does that are progeny of true crossbred does and bucks from a paternal line. The frequency of self-replacement can be nonnegligible when the price of rabbit meat is low (Ramón and Rafel, 2002).

Table 4. Contrasts at foundation between lines (A, V, H and LP) for functional longevity.

\begin{tabular}{lccccc}
\hline \multicolumn{1}{c}{ Trait } & $\mathrm{A}-\mathrm{V}$ & $\mathrm{A}-\mathrm{H}$ & $\mathrm{A}-\mathrm{LP}$ & $\mathrm{V}-\mathrm{H}$ & $\mathrm{V}-\mathrm{LP}$ \\
\hline Logarithm of the risk & 0.50 & 0.70 & 1.15 & 0.05 & 0.44 \\
& $\pm 0.23^{*}$ & $\pm 0.28^{*}$ & $\pm 0.32^{*}$ & \pm 0.19 & $\pm 19^{*}$ \\
Relative risk & 1.64 & 2.01 & 3.15 & 1.05 & 1.55 \\
\hline *. & 1.00 &
\end{tabular}

The contrasts regarding longevity are shown in Table 4 (El Nagar, 2015). In this table, a positive value of the contrast for the logarithm of the risk means that the does of the first line have a higher risk of being eliminated and, consequently, lower longevity. Correspondingly, a value of the contrast for the relative risk higher than 1 means that the does of the first line have a higher probability of death or culling that the does of the second, because the relative risk is the quotient between the risks of both lines. The lines V, H and LP showed a substantial superiority over line A. The maximum relative risks was observed between the lines LP and A. The relative risk describes how much more likely it is that culling or death occurs within one level of a given factor relative to another level of the same factor. For instance, at foundation it was 3.15 times more likely for a line A doe to be culled/died than for a LP doe. Line LP was created from does that had at least 25 parities (Sánchez et al., 2008). The results showed in Table 4, as it has been also commented for Tables 2 and 3, have apparent inconsistencies, for example, the difference between lines $\mathrm{A}$ and $\mathrm{V}$ at their foundation was 0.495 and between lines A and LP was 1.148. Their difference, $(1.148-0.495)$ is not exactly 0.436 , the contrast between lines V and LP. This deviation between the two values is due to the different sets of year-seasons involved in each particular contrast and to the inclusion of the line-year-season interaction in the model. The longer 
productive life of LP does could be considered as an indicator of the successful foundation procedure of this line. On the other hand, the line A was created by mating does and bucks of the New Zealand White breed belonged to commercial populations maintaining the standard morphological characteristics of the breed. In addition, line A had a high susceptibility, already commented, to enter ocolitis disease which was present during some periods shared with the other lines (Ragab and Baselga, 2011). Piles et al. (2006) found relevant differences in the genetic effects for functional longevity between maternal rabbit lines A, V and Prat and the crossbred females from them. They stated that a doe was twice as likely to be replaced than a crossbred Prat $\times \mathrm{A}$ doe, and in general the genetic types with the highest relative risks were those in which the A line participated. In another study comparing two maternal lines of rabbits, Sánchez et al. (2008) indicated the superiority of the line LP over the line $\mathrm{V}$ in survival ability, especially at later cycles. They attributed this result to the selection procedure in the LP line which was focused on late survival. Moreover, the comparison between LP and V lines was not a comparison at foundation time because for $\mathrm{V}$ line only the closest relationships were considered in the study. In contrast, in the present study all the available pedigree information was used.

\section{Conclusions}

Important differences were detected for litter size, fertility, growth and longevity between the lines attheir origin, which can be explained based on the selectioncriteria used at the time of their foundation. Differences werealso affected by interactions between year-seasons andlines. Therefore, all the issues related with the foundation of a new line should be carefully considered. The foundation of a line exclusively based on the concept of breed - as in the case of the A line - without considering production criteria seems less suitable than other criteria more closely related to production.

\section{Selection and response to selection}

Paternal lines are commonly selected for post-weaning daily gain (Rochambeau et al., 1989; Estany et al., 1992; Gómez et al., 2002) or for a weight at a time close to the market age (Lukefahr et al., 1996; Larzul et al., 2003a; Drouilhet et al., 2013). These criteria are very easy to record and have a negative and favourable genetic correlation with the conversion index (Moura et al., 1997; Piles et al., 2004; Drouilhet et al., 2013).The economic weight of this traitis very important (Cartuche et al., 2014) and, recently, it has been included as adirect objective of selection by French 
rabbit breeder Hypharm(Garreau et al., 2013).In Hungary, the paternal line Pannon, founded in 2004, is selected for daily gain and muscle volume of the thigh, measured by computerized tomography (Nagy et al., 2013). Carcass yield and resistance to digestive troubles are being considered in the selection of the paternal lines AGP39 y AGP59 of Hypharm (Garreau et al., 2008b).

The responses reported in experiments of selection for weight at market time, 63-70d, range between 18 and $35 \mathrm{~g}$ per generation (Rochambeau et al., 1994; Lukefahr et al., 1996; Garreau et al., 2000; Larzul et al., 2003a). At a fixed slaughter weight, with the progress of selection, the feed conversion decreases and feed consumption increases (Feki et al., 1996); intestinal content increases, and the dressing percentage is reduced (Gómez et al., 1998; Pla et al, 1998) because of the lower maturity. Consequences of this lower maturity are also reduced fat deposits, diminished water holding capacity of the meat (Piles et al., 2000) and lower ultimate $\mathrm{pH}$ in muscle (Gondret et al., 2003). Some of the negative consequences of selection for growth rate are not quantitatively important and can be reduced by increasing the market weight and imposing a light fasting before slaughter. In an analysis at a constant age, the improvement in the conversion index can disappear as well as the negative effects on dressing percentage and maturity (Garreau et al., 2000; Larzul et al., 2003b). The efficiency of the computer tomography aided selection is observed, for instance, in the Pannon terminal line, where the estimated annual genetic trend for the thigh muscle volume was $5.8 \mathrm{~cm}^{3}$ (Nagy et al., 2013).

The most common criteria for selection of maternal lines have been related with litter size at birth or at weaning (Estany et al., 1989; Rochambeau et al., 1994; Gómez et al., 1996; Nagy et al., 2011). Only in one case, the selection criteria included litter size at birth and kit weight at nine weeks of life to prevent negative responses in adult body weight (Bolet and Saleil, 2002). However, different selection criteria have been proposed, as alternative methods, in order to improve response to selection for litter size or the ability of the doe to nourish the lactating progeny and avoid kit mortality.Thus, some programs include the individual weight at weaning (Garreau and Rochambeau, 2003; Garreau et al., 2005), the litter weight at weaning or the total milk yield. In Italy, two maternal lines, respectively based on the New Zealand White and Californian breeds, are selected for the individual weight at $60 \mathrm{~d}$ and the litter weight at $19 \mathrm{~d}$.The Italian program also gives some importance to the number of teats. In France, some companies apply methods to improve the uniformity of the 
birth weight (Garreau et al. 2008a), and functional longevity is, currently, an objective of selection for the line AGP77 of Hypharm.

Regarding the response to selection in maternal lines, the estimated responses ranged between 0.08-0.09 total born, born alive or weaned rabbits per litter and generation (Rochambeau et al., 1998; García y Baselga, 2002 a \& b; Tudela et al., 2003).The correlated responses on growth traits when selection is for litter size have been also investigated and Baselga y García (2002) and García y Baselga (2002c) did not find significant responses for the weights at weaningand at slaughter, for average daily gain, feed consumption and conversion index when the comparisons were made to a constant litter size at birth. However, Rochambeau et al. (1994) reported a decrease in the individual weight at weaning when selecting to increase litter size.

\section{REFERENCES}

Baselga M. 2002. Line V (Spain). En: Khalil M.H., Baselga M. (Eds.)Rabbit genetic resources in Mediterranean countries. CIHEAM, Zaragoza, España, pp. 231-241.

Baselga M. 2004. Genetic improvement of meat rabbits. Programmes and diffusion. En: $8^{\text {th }}$ World Rabbit Congress. Puebla, Mexico, pp. 1-13.

Baselga M. and García M.L. 2002. Evaluating the response to selection in meat rabbit programmes. En: $3^{\text {rd }}$ Scientific Conference of Rabbit Production in Hot Climates. Hurghada, Egipto, pp. 1-10.

Blasco A. 1996. Genetics of litter size and does fertility in the rabbit. In: 6th World Rabbit Congress, 1996 July, Toulouse, France 2: 219-227.

Bolet G., Saleil G. 2002. Strain INRA1077 (France). En: Khalil M.H., Baselga M. (Eds.)Rabbit genetic resources in Mediterranean countries. CIHEAM. Zaragoza, España, pp. 109-116.

Cartuche L., Pascual M., Gómez E. A., Blasco A. 2014. Economic weights in rabbit meat production. World RabbitSci. 22:165-177.

Cifre P., Baselga M., García-Ximénez F., Vicente J.S. 1998a. Performance of a hyperprolific rabbit line I. Litter size traits. J. Anim. Breed. Genet., 115(2):131-138.

Cifre P., Baselga M., García-Ximénez F., Vicente J.S. 1998b. Performance of a hyperprolific rabbit line II. Maternal and growth performances. $J$. Anim. Breed. Genet., 115(2):139-147.

Drouilhet L., Gilbert H., Balmisse E., Ruesche J., Tircazes A.,Larzul C., Garreau H.2013. Genetic parameters for two selection criteria for feed efficiency in rabbits. Journal of Animal Science 91, 3121-3128 
EL Nagar A. 2015. Genetic analysis of longevity in specialized lines of rabbits. Tesis doctoral. Universidad Politécnica de Valencia, Valencia, España.

Estany J., Baselga M., Blasco A., Camacho J. 1989. Mixed model methodology for the estimation of genetic response to selection in litter size of rabbits. Livest. Prod. Sci., 21:67-76.

Estany J., Camacho J., Baselga M., Blasco A. 1992. Selection response of growth rate in rabbits for meat production. Génét. Sel. Evol., 24:527-537.

Feki S., Baselga M., Blas E., Cervera C., Gómez E.A. 1996. Comparison of growth and feed efficiency among rabbit lines selected for different objectives. Livest. Prod. Sci., 45:87-92.

Ferrian S., Blas E., Larsen T., Sánchez J.P., Friggens N.C., Corpa J.M., Baselga M., Pascual J.J. 2013. Comparison of immune response to lipopolysaccharide of rabbit does selected for litter size at weaning or founded for reproductive longevity. Res. Vet. Sci.,94:518-525.

García M.L., Baselga M. 2002a. Estimation of genetic response to selection in litter size of rabbits using a cryopreserved control population. Livest. Prod. Sci., 74:45-53.

García M.L., Baselga M. 2002b. Genetic response to selection for reproductive performance in a maternal line of rabbits. World Rabbit Sci.,10(2):71-76.

García M.L., Baselga M. 2002c. Estimation of correlated response on growth traits to selection in litter size of rabbits using a cryopreserved control population and genetic trends. Livest. Prod. Sci., 78(2):91-98.

García-Ximénez F., Vicente J.S., Cifre P., Baselga M. 1996. Foundation of a maternal rabbit line using hysterectomy and embryo cryopreservation. En: 6th World RabbitCongress, Toulouse, France, pp. 2:285-288.

Garreau H., Rochambeau H. de 2003. La sélection des qualités maternelles pour la croissance du laperau. En: $10^{\text {èmes }}$ Jour. Rech. Cunicole. Paris, France, pp. 61-64.

Garreau H., Piles M., Larzul C., Baselga M., Rochambeau H. de 2004. Selection of maternal lines: last results and prospects. In: Proc. 8th World Rabbit Congress, 2004 September, Puebla, Mexico.

Garreau H., Szendro Z.S., Larzul C., Rochambeau H. de 2000. Genetic parameters and genetic trends of growth and litter size traits in the White Pannon breed. En: $7^{\text {th }}$ World Rabbit Congress. Valencia, España, pp. A:403-408.

Garreau H., Duzert R., Tudela F., Baillot C., Ruesche J., Grauby H., LilleLarraucau C., Rochambeau, H. de 2005. Gestion et sélection de la souche INRA 1777: Résultats de trois générations de sélection. En: $11^{\text {ème }}$ Journées de la Recherche Cunicole. Paris, France, pp. 19-22. 
Garreau H., Bolet G., Larzul C., Robert-Granié C., Saleil G., Sancristobal M., Bodin L. 2008a. Results of four generations of a canalising selection for rabbit birth weight. Livest. Sci.,119(1-3):55-62.

Garreau H., Eady S.J., Hurtaud J., Legarra A. 2008b. Genetic parameters of production traits and resistance to digestive disorders in a commercial rabbit population. En: $9^{\text {th }}$ World RabbitCongress. Verona, Italy, pp. 103107.

Garreau H., Hurtaud J., Drouilhet L. 2013. Estimation des paramètres génétiques de la croissance et de l'efficacité alimentaire dans deux lignées commerciales. En: $15^{\text {ème }}$ Journées de la Recherche Cunicole. Paris, France, pp. 15-18.

Gómez E.A., Baselga M., Rafel O., Ramon J. 1998. Comparison of carcass characteristics in five strains of meat rabbit selected on different traits. Livest. Prod. Sci.,55:53-64.

Gómez E. A., Rafel O., Ramón J. 2002. The Caldes strain. En: Khalil M.H., Baselga M. (Eds) Rabbit genetic resources in Mediterranean countries. CIHEAM. Zaragoza, España, pp. 187-198.

Gómez E. A., Rafel O., Ramón J., Baselga M. 1996. A genetic study of a line selected on litter size at weaning. En: $6^{\text {th }}$ World RabbitCongress, Toulouse, France, pp. 2:289-292.

Gondret F., Combes S., Larzul C. 2003. Sélection divergente sur le poids a 63 jours: conséquences sur les caractéristiques musculaires à même âge ou à même poids. En: $10^{\text {èmes }}$ Jour. Rech. Cunicole. Paris, France, pp. 153-156.

Khalil M.H., Baselga M. (Eds.) 2002. Rabbit genetic resources in Mediterranean countries. CIHEAM. Zaragoza, España.

Khalil M.H., Al-Saef A.M. 2008. Methods, criteria, techniques and genetic responses for rabbit selection: a review. In: Proc. 9th World Rabbit Congress, 2008 June, Verona, Italy.

Khalil M.H., Bolet G. 2010. Sustainable rabbit breeding and genetic improvement programs achieved in developing countries. In: Proc. 9th World Congress on Genetics Applied to Livestock Production, 2010 August, Leipzig, Germany.

Larzul C., Gondret F., Combes S., Garreau H., Rochambeau H. de 2003a. Analyse d'une expérience de sélection sur le poids à 63 jours: IDéterminisme génétique de la croissance. En: $10^{\text {èmes }}$ Jour. Rech. Cunicole. Paris, France, pp. 149-152.

Larzul C., Gondret F., Combes S., Garreau H., Rochambeau H. de 2003b. Analyse d'une expérience de sélection sur le poids à 63 jours: IIDéterminisme génétique de la composition corporelle. En : $10^{\text {èmes }}$ Jour. Rech. Cunicole. Paris, France, pp. 145-148. 
Lukefahr S.D., Odi H.B., Atakora J.K.A. 1996. Mass selection for 70 body weight in rabbits. J. Anim. Sci., 74:1481-1489.

Matheron G., Poujardieu B. 1984. La génétique du lapin : le point, les perspectives. In : Proc. 3rd World Rabbit Congress, 1984 June, Rome,Italy, 1:3-34.

Mínguez C. 2014. Genetic analyses of growth, carcass and meat quality traits in maternal lines of rabbits and their diallel cross. Tesis doctoral. Universidad Politécnica de Valencia, Valencia, España.

Mocé M.L., Santacreu M.A. 2010. Genetic improvement of litter size in rabbits. In: Proc. 9th World Congress on Genetics Applied to Livestock Production, 2010 August, Leipzig, Germany

Moura A.S.A.M.T.M., Kaps M., Vogt D.W. Lamberson M. 1997. Two-way selection for daily gain and feed conversion in a composite rabbit population. J. Anim. Sci.,75:2344-2349.

Nagy I., Radnai I., Nagyné-Kiszlinger H., Farkas J. SzendrőZs. 2011. Genetic parameters and genetic trends of reproduction traits in synthetic Pannon rabbits using repeatability and multi-trait animal models. ArchivTierzucht 54, 297-307.

Nagy I., Gyovai P., Radnai I., Nagyné-Kiszlinger H., Farkas J., SzendröZs. 2013. Genetic parameters, genetic trends and inbreeding depression of growth and carcass traits in Pannon terminal line rabbits. Archiv. Tierzucht.,56:191-199.

Piles M., Blasco A., Pla M. 2000. The effect of selection for growth rate on carcass composition and meat characteristics of rabbits. Meat Sci.,54:347355.

Piles M., Gómez E.A., Rafel O., Ramon J., Blasco A. 2004. Elliptical selection experiment for the estimation of genetic parameters of the growth rate and feed conversion ratio in rabbits. J. Anim. Sci., 82:654660.

Piles, M., J. P. Sánchez, J. Orengo, O. Rafel, J. Ramon, M. Baselga. 2006. Crossbreeding parameter estimation for functional longevity in rabbits using survival analysis methodology. J. Anim. Sci., 84:58-62.

Pla M., Guerrero L., Guardia D., Oliver M.A., Blasco A. 1998. Carcass characteristics and meat quality of rabbit lines selected for different objectives. I. Between lines comparison. Livest. Prod. Sci., 54:115-123.

Ragab M., Baselga M. 2011. A comparison of reproductive traits of four maternal lines of rabbits selected for litter size at weaning and founded on different criteria. LivestockScience, 136:201-206.

Ramón J., Rafel O. 2002. 1991-2000. Diez años de gestión global en España. In: Expoaviga 2002. X Jornadas Cunicolas. Barcelona, Spain. pp : 113-117. 
Rochambeau H. de. 1988. Genetics of the rabbit for wool and meat production. In: Proc. 4th World Rabbit Congress, 1988 October, Budapest, Hungary.

Rochambeau H. de, Bolet G., Tudela F. 1994. Long term selection. Comparison of two rabbit strains. En: $5^{\text {th }}$ World Congress on Genetics Applied to Livestock Production. Guelph, Canada, pp. 19: 257-260.

Rochambeau H. de, Duzert R., Tudela F. 1998. Long term selection experiments in rabbit. Estimation of genetic progress on litter size at weaning. En: $6^{\text {th }}$ World Congress on Genetics Applied to Livestock Production. Armidale, NSW, Australia, pp. 26: 112-115.

Rochambeau H. de, Fuente L.F. de la, Rouvier R. 1989. Sélection sur la vitesse de croissance post-sevrage chez le lapin. Génét. Sél. Evol., 21:527-546.

Rouvier R. 1980. Génétique du lapin (Oryctolaguscuniculus). In: Proc. $2^{\text {nd }}$ World Rabbit Congress, 1980 April, Barcelona, Spain

Rouvier R. 1981. Les travaux de recherche français sur la sélection du lapin au cours des 10 dernières années (1970-1980). CR. Acad. Agri. Fr., 61: 151-159.

Sánchez J.P., Theilgaard P., Minguez C., Baselga M. 2008. Constitution and evaluation of a long-lived productive rabbit line. J. Anim. Sci., 86:515525 .

Savietto D., Blas E., Cervera C., Baselga M., Friggens N.C., Larsen T., Pascual J.J. 2012. Digestive efficiency in rabbit does according to environment and genetic type. World Rabbit Sci., 20:131-140.

Theilgaard P., Sánchez J.P., Pascual J.J., Berg P., Friggen, N., Baselga M. 2007. Late reproductive senescence in a rabbit line hyper selected forreproductive longevity, and its association with body reserves. Genet. Sel. Evol. 39, 207-223.

Theilgaard P., Baselga M., Blas E., Friggens N.C., Cervera C., Pascual J.J. 2009. Differences in productive robustness in rabbits selected for reproductive longevity or litter size. Animal,3:637-646.

Tudela F., Hurtaud J., Garreau H., Rochambeau H. de 2003. Comparaison des performances zootechniques des femelles parentales issues d'une souche témoin et d'une souche sélectionnée pour la productivité numérique. En: 10 èmes Jour. Rech. Cunicole. Paris, Francia, pp. 53-56.

Youssef Y.K., Iraqi M.M., El-Raffa A.M., Afifi E.A., Khalil M.H., Garcia M.L., Baselga M. 2008. A join project to synthesize new lines of rabbits in Egypt and Saudi Arabia: emphasis for results and prospects. En: $9^{\text {th }}$ World Rabbit Congress. Verona, Italia, pp. 1637-1641. 